\title{
Interactive Effect of Zinc Foliar application and Potassium Fertilizer on Productivity and Grains quality of Wheat
}

\author{
Abido W.A.E. ${ }^{1}$ and Rasha S.A. El-Moursy ${ }^{2}$ \\ ${ }^{1}$ Agronomy Department, Faculty of Agriculture, Mansoura University, Egypt. \\ ${ }^{2}$ Agronomy Department, Faculty of Agriculture, Damietta University, Egypt. \\ Received: 30 Dec 2019/ Accepted 10 Feb. 2020 / Publication date: 15 April. 2020
}

\begin{abstract}
In order to study the response of wheat growth, yield, yield characteristics and grains chemicals analysis to zinc $(\mathrm{Zn})$ foliar treatments under top dressing of potassium $(\mathrm{K})$ fertilizer levels, two field experiments were conducted at the Experimental Farm, Faculty of Agriculture, Mansoura University, Egypt, during 2017/2018 and 2018/2019 seasons. The experiments were laid out in a strip-plot design with three replicates, each experiment comprising of twenty-five different treatments of five zinc foliar application treatments (without as control, spraying with water, 150, 300 and $450 \mathrm{~g} \mathrm{Zn} / \mathrm{fed}$ ) were allocated at the vertical-plots. While, the horizontal-plots were devoted to five potassium fertilizer levels $\left(0,14,28,42\right.$ and $\left.56 \mathrm{~kg} \mathrm{~K}_{2} \mathrm{O} / \mathrm{fed}\right)$ as top dressing. The results showed that zinc foliar application treatments significantly increased growth, yields and its attributes and grain quality of wheat plants and the highest values of all characters under study were recorded with $450 \mathrm{~g} \mathrm{Zn} / \mathrm{fed}$ compared with the other foliar application in both seasons. Potassium fertilization positively enhanced the growth, yield characters and grains quality of wheat. Application of $56 \mathrm{~kg} \mathrm{~K}_{2} \mathrm{O} /$ fed produced the highest values of most studied traits and without significant differences with $42 \mathrm{~K}_{2} \mathrm{O} /$ fed as compared with other potassium levels during both growing seasons. Therefore, the current study detected that foliar application with $450 \mathrm{~g} \mathrm{Zn} / \mathrm{fed}$ ), besides potassium soil addition at $42 \mathrm{~K}_{2} \mathrm{O}$ /fed to improve the productivity and grain qualities of wheat Gemiaza11 cultivar under the same environmental conditions of the agriculture area.
\end{abstract}

Keywords: Wheat, zinc foliar application $(\mathrm{Zn})$, potassium $(\mathrm{K})$ fertilizer, growth, yield, grains chemical analysis.

\section{Introduction}

Wheat (Triticum aestivum var. vulgare L.) is consider the king of cereal crops due to its important role as a staple food and the second most important human nutritive value, which the grains of wheat provides about $20 \%$ of the total calories, high percentage of protein about $15 \%$ compared with other cereal crops and the straw of wheat using in animals feeding (Fischer, 2008). It has a relatively high percentage of thiamin and niacin as well as its essentially considered in providing the gluten, which plays essential role in baking processes and a strategic commodity (El-Habbasha et al., 2015 and Vora et al., 2019). Total cultivated area in Egypt of wheat during 2018 season reached about (3.130 million) feddan with total production (8.8 million tons), while in the world reached about (511.203 million feddan) with total production (735.2 million tons) FAO, (2020). There is a big gap in Egypt among the consumption and production of wheat due to the continues increases in the human population and the shortage of cultivated area.

One of the most essential micronutrients for plant or human is Zinc ( $\mathrm{Zn})$, according to the world health organization report (WHO, 2002) there is lack of $\mathrm{Zn}$ in human people of developing countries and a lot of people in these countries have diseases and death due to $\mathrm{Zn}$ deficit. The deficiencies of this nutrient resulted decrease in grains yield and serious human health problems (Vora et al., 2019). The main roles of zinc is a catalytic which, propensity to make up tetragonal compounds with oxygen, nitrogen and sulfur, building and activating role in the enzymes and it has play important roles either as a functional or as a metal element of enzyme i.e alcohol dehydrogenase and carbonic anhydrase, these enzymes are too essential for dehydration and increasing the absorption of $\mathrm{CO}_{2}$ and maximizing the photosynthesis rate and consequently biomass production (Galavi et al., 2011 and Maleki et al., 2014), as well as regulatory co-factor of a great number of enzymes (Hotz and Braun, 2004). Besides, Zn have a great influence on basic plant life processes i.e. cell division, stomatal regulation and respiration (Zhu Corresponding Author: Abido W.A.E., Agronomy Department, Faculty of Agriculture, Mansoura University, Egypt. E-mail: madawy78@mans.edu.eg 
et al., 2015), nitrogen uptake and metabolism, protein quality, carbon anhydrase activity, photosynthesis, auxin and chlorophyll synthesis (Jiang et al., 2013), biomass production, pollen function and pollination, resistance to a biotic stress (Pandey et al., 2006; Cakmak, 2008 and Potarzycki and Grzebisz, 2009). The technique of fertilization foliar application methods plays vital role to modify the shortages of some essential nutrients in soil and increase the inability of soils to transfer nutrients into tissue of plant as well as enhance nutrient use efficiency by plants (Mosali et al., 2006). In this regard, several researchers have been focused to maximize growth, yield, yield characteristics as well as grain quality of wheat plants, in this regard, the suitable application of micronutrients such as $\mathrm{Zn}$ especially with balanced portion of potassium K (Zeidan et al., 2010). Wheat plants responds to foliar application of some micronutrients during its growing stages and results in enhanced output in terms of yield. Researchers reported that application of zinc fertilizer either to the soil or foliar application is considered one of the actual and productive ways to enhancement the growth, yield, yield characteristics and $\mathrm{Zn}$ content of cereal grains (Cakmak, 2008; Seadh et al., 2009; El-Metwally et al., 2012 and Ahmed Akram et al., 2017). Also, foliar application with $\mathrm{ZnSO} 4$ as a source of $\mathrm{Zn}$ had positive effect on wheat growth, grain yield, yield characteristics as well as grains zinc, $\mathrm{P}$ and $\mathrm{K}$ contents (Zeidan et al., 2010; El-Habbasha et al., 2015, Esfandiari et al., 2016 and Hassanein et al., 2019). Foliar application of Zn at the rate of $400 \mathrm{~g}\left(\mathrm{ZnSo}_{4} .7 \mathrm{H}_{2} \mathrm{O}\right)$ produced the highest values of growth, yield and yield characteristics, grain protein, (El-Dahshouri, 2018). On maize and rice plants, (Wasaya et al., 2017 and Muthukumararaja and Sriramachandrasekharan 2020) depicted that Zn foliar application had positive effect on chlorophyll content, growth characters, yield attributes and grains yield and its qualities.

Potassium $(\mathrm{K})$ is considered as one of the most vital macro nutrient came after nitrogen and phosphorous (Dhillon et al., 2019). It is a dynamic element into plant tissue and plays important roles in many functions in physiological and metabolic and biochemical of plants, which helps in protein synthesis, translocation of photosynthates products, regulator of ionic balance and plant stomata, the root development, increases the efficiency of nitrogen and water use (Reddya et al., 2004), osmoregulation, enzyme activity, increase the resistance of plants for diseases, cold and drought (Wang et al., 2013). Thus, it is necessary to ensure suitable potassium for wheat. In this regard, application potassium at $100 \mathrm{~kg} \mathrm{~K} 2 \mathrm{O} / \mathrm{ha}$ recorded the highest growth characters and yield of wheat plants (Tahir et al., 2008). Also, increasing the amount of potassium fertilizer caused increasing in growth, yield of wheat and grains K and Zn contents (Khan and Jan, 2014 and Dincsoy and Sonmez, 2019). Brhane and Teka (2018) noticed that biological and economical yield of wheat plants positively influenced due to potassium mineral fertilizer and the highest values of these characters were recorded when plants received $90 \mathrm{~K}_{2} \mathrm{O} \mathrm{kg} / \mathrm{ha}$.

Concerning to the interaction influence of zinc foliar application under potassium fertilizer levels on wheat productivity. In this connection, application $375 \mathrm{~kg} / \mathrm{ha}$ of potassium fertilizer in combination with $15 \mathrm{~kg} /$ ha of zinc significantly improved the growth and yield characters of wheat plants (Jan et al., 2012 and Arif et al., 2017). Moreover, Sharma et al., (2018) noticed that the application of $30 \mathrm{~kg} / \mathrm{ha}$ of potassium beside $25 \mathrm{~kg} /$ ha of zinc increasing growth characters, yield, grains potassium and zinc contents of wheat plants.

So, the aim of the field study was to evaluate the interactive effect of zinc foliar application under potassium fertilizer levels as soil addition on the productivity and grains quality of wheat plants under the environmental conditions of Dakahlia Governorate, Egypt.

\section{Materials and Methods}

\section{Study site and objective:}

The field experiment was laid out at the Experimental Farm, Faculty of Agriculture, Mansoura University, Egypt, during 2017/2018 and 2018/2019 seasons. The study was conducted in order to study the response of wheat cultivar Gemieza 11 growth, yields and its components as well as grain quality characters to zinc foliar and potassium fertilizer levels treatments as well as their interactions. The Egyptian wheat cultivar (Gemieza 11) under study was obtained from Wheat Res., Section, Field Crops Res. Institute of Agric. Res. Center, Giza, Egypt. 


\section{Experimental design and treatments:}

The experiments were conducted in a strip-plot design with three replicates. Each experiment included twenty five different treatments of five zinc foliar application and five potassium fertilizer levels as top dressing. The vertical-plots were included zinc foliar application (without as control, spraying with water, 150, 300 and $450 \mathrm{~g} \mathrm{Zn} /$ feddan), $\mathrm{Zn} \mathrm{SO}_{4} .7 \mathrm{H}_{2} \mathrm{O}$ was used as source of zinc. The vertical-plots were received foliar solution volume (200 Liter/fed) until saturation point by using hand sprayer, the solution was sprayed after 35 and 50 days (during tillering and elongation growth stage). While, the horizontal-plots were devoted to potassium fertilizer levels (Without (0), 14, 28, 42 and 56 $\left.\mathrm{kg} \mathrm{K}_{2} \mathrm{O} / \mathrm{fed}\right)$ as top dressing. Potassium fertilizer in the form of potassium sulphate $\left(48.0 \% \mathrm{~K}_{2} \mathrm{O}\right)$ was added before the $2^{\text {nd }}$ and $3^{\text {rd }}$ irrigations, respectively.

\section{Agricultural practices:}

Soil samples were taken from each plot at random digging soil at 0 to $15 \mathrm{~cm}$ and 15 to $30 \mathrm{~cm}$ depth for analyze the physical and chemical characteristics in both growing seasons as presented in Table 1.

Table 1: Physical and chemical characteristics during 2017/2018 and 2018/2019 seasons.

\begin{tabular}{|c|c|c|c|c|c|c|c|c|c|c|c|}
\hline \multicolumn{12}{|c|}{ Physical characteristics } \\
\hline Seasons & $\begin{array}{l}\text { Coarse } \\
\text { sand } \\
(\%)\end{array}$ & $\begin{array}{l}\text { Fine } \\
\text { sand } \\
(\%)\end{array}$ & $\begin{array}{l}\text { Silt } \\
(\%)\end{array}$ & $\begin{array}{l}\text { Clay } \\
(\%)\end{array}$ & \multicolumn{3}{|c|}{ Soil texture } & $\begin{array}{c}\mathrm{CaCO}_{3} \\
(\%)\end{array}$ & \multicolumn{3}{|c|}{$\begin{array}{c}\text { Field capacity } \\
(\%)\end{array}$} \\
\hline $2017 / 2018$ & 6.5 & 33.2 & 25.9 & 34.4 & \multicolumn{3}{|c|}{ Clay loam } & 2.4 & \multicolumn{3}{|c|}{35.7} \\
\hline 2018/2019 & 6.3 & 32.6 & 27.0 & 34.1 & \multicolumn{3}{|c|}{ Clay loam } & 2.5 & \multicolumn{3}{|c|}{35.1} \\
\hline \multicolumn{12}{|c|}{ Chemical characteristics } \\
\hline \multirow[t]{2}{*}{ Seasons } & \multirow[t]{2}{*}{ pH } & \multirow[t]{2}{*}{$\begin{array}{c}\mathbf{E C} \\
\mathrm{dSm}^{-1}\end{array}$} & \multirow{2}{*}{\multicolumn{2}{|c|}{$\begin{array}{c}\text { Organic } \\
\text { matter }(\%)\end{array}$}} & \multicolumn{3}{|c|}{$\begin{array}{c}\text { Available } \\
\text { macronutrients } \\
\text { nutrients (ppm) }\end{array}$} & \multicolumn{4}{|c|}{$\begin{array}{l}\text { Available micronutrients } \\
\text { nutrients (ppm) }\end{array}$} \\
\hline & & & & & $\mathbf{N}$ & $\mathbf{P}$ & $\mathbf{K}$ & $\mathbf{F e}$ & Mn & $\mathbf{Z n}$ & $\mathbf{C u}$ \\
\hline $2017 / 2018$ & 7.7 & 1.9 & & & 32.3 & 7.1 & 232 & 2.7 & 1.5 & 1.0 & 0.7 \\
\hline 2018/2019 & 7.6 & 1.1 & 2 & & 36.4 & 7.3 & 240 & 3.6 & 1.7 & 1.2 & 0.9 \\
\hline
\end{tabular}

The experiment contains seventy five experimental units, each unit area was 3 X 3.5 m occupying an area of $10.5 \mathrm{~m}^{2} ; 1 / 400$ feddan (one feddan (fed) equal $4200 \mathrm{~m}^{2}$ ). The previous summer crop was rice plant (Zea mays L.) during both seasons. Phosphorous in the form of calcium superphosphate $(15.5 \%$ $\left.\mathrm{P}_{2} \mathrm{O}_{5}\right)$ at the amount of $150 \mathrm{~kg} / \mathrm{fed}$ was applied to the soil during soil preparation. Nitrogen at the recommended dose of $(70 \mathrm{~kg} \mathrm{~N} / \mathrm{fed})$ was added in the form of ammonium nitrate $(33.5 \% \mathrm{~N})$ in three equal portions, the first dose with planting date, the $2^{\text {nd }}$ and $3^{\text {rd }}$ doses before the $1^{\text {st }}$ and $2^{\text {nd }}$ irrigations and finished before heading stage. The optimum seeding rate of $70 \mathrm{~kg} /$ fed were broadcasted using method (Afir) on the last third of November $\left(26^{\text {th }}\right)$ for both growing seasons. The supplementary applies of wheat cultivation in the studied area were applied according to the guidance of the Ministry of Agriculture and Land Reclamation, excluding factors under study.

\section{Studied characters:}

After 90 days from sowing (DFS), ten plants were collected randomly from each plot to estimate the following vegetative growth characters; 1 - Total chlorophyll (SPAD): In flag leaf, total chlorophyll content was estimated by using SPAD-502 (Minolta Co. Ltd., Osaka, Japan); 2- Flag leaf area ( $\left.\mathrm{cm}^{2}\right)$ : It was estimated by using Leaf Area Meter, (AM-300, Bio-Scientific, Ltd., Great Am well, Herefordshire, England) and 3- Plant height ( $\mathrm{cm})$.

At maturity (150 DFS), one $\mathrm{m}^{2}$ was selected randomly from each plot to measure; 1 - Number of spikes $/ \mathrm{m}^{2} ; 2$ - Spike length (cm); 3- Number of grains/spike; 4- Grains weight/spike (g); 5- 1000-grain weight (g); 6- Grain yield (ardab/fed). It was calculated by harvesting all of plants in each experimental plot, air dried, threshed after that the grains were adjusted to a 13.5\% moisture, then weighted in $\mathrm{kg}$ and converted to $\mathrm{ardab} / \mathrm{fed}$ (one ardab $=150 \mathrm{~kg}$ ) and 7- Straw yield (ton/fed). The straw obtained from previous sample was weighted in $\mathrm{kg} / \mathrm{plot}$ after that converted to ton/fed.

Grains chemical analysis were included; 1- Carbohydrates content (\%): It was estimated by using the anthrone technique as defined by Sadasivam and Manickam (1996); 2- Protein content (\%): It was 
assessed by using the improved Kjeldahl-method according to AOAC (2016); 3- Phosphorus content (\%). It was estimated according to AOAC (2016); 4- Potassium contents (\%) were determined using flamephotometer as described by Jackson (1967) and 5-Zinc content (ppm): was estimated using atomic absorption spectrometer, Perkin-Elmer (1100 B) according to AOAC (2016).

\section{Statistical analysis:}

The technique of analysis of variance (ANOVA) using (MSTAT-C, MGRAPH version 2.10, Crop and Soil Sci., Dept., Michigan State Univ., USA) for a strip plot design was used for data analysis (Gomez and Gomez, 1984), developed by Russel (1986). The method of Least Significant Differences (LSD) was used to test the variances among treatment means at probability of $5 \%$ level according to Snedcor and Cochran (1980).

\section{Results and Discussion}

\section{A-Vegetative growth characters:}

Results showed in Table 2 revealed that vegetative growth characters of wheat plants i.e. total chlorophyll content (SPAD), flag leaf area $\left(\mathrm{cm}^{2}\right)$ and plant height $(\mathrm{cm})$ were significantly increased with foliar application with water and zinc as compared with control treatment (without spraying) in both seasons. Foliar application with the highest levels of zinc $\left(450 \mathrm{~g}\right.$ of $\left.\mathrm{ZnSO}_{4} .7 \mathrm{H}_{2} \mathrm{O}\right)$ produced the maximum values of total chlorophyll (44.70 and $44.74 \mathrm{SPAD})$, flag leaf area $\left(88.35\right.$ and $\left.89.98 \mathrm{~cm}^{2}\right)$ and plant height $(106.60$ and $108.58 \mathrm{~cm})$ in both growing seasons, respectively. The increases in above mentioned vegetative growth characters due to zinc foliar application at $450 \mathrm{~g} \mathrm{ZnSO} .7 \mathrm{H}_{2} \mathrm{O}$ reached about $(22.34,18.56$ and $17.17 \%)$ compared with control treatment as average over both seasons. The increase of vegetative growth characters of wheat plants due to foliar application with the high levels of $\mathrm{Zn}\left(450 \mathrm{~g} \mathrm{ZnSO}{ }_{4} .7 \mathrm{H}_{2} \mathrm{O}\right)$ might be ascribed to the vital role of $\mathrm{Zn}$ either as a functional or as a metal component of many enzymes (Hotz and Braun, 2004), increasing the absorption of $\mathrm{CO}_{2}$ and maximizing the photosynthesis rate, auxin and chlorophyll synthesis (Galavi et al., 2011; Jiang et al., 2013 and Maleki et al., 2014). Moreover, the important role of $\mathrm{Zn}$ in the processes of cell division, stomatal regulation and respiration (Zhu et al., 2015). The obtained results are concord with those noticed by Cakmak (2008); El-Metwally et al. (2012); Esfandiari et al. (2016); Ahmed Akram et al. (2017); ElDahshouri (2018) and Hassanein et al. (2019)

Potassium fertilizer rates (without, 14, 28, 42 and $56 \mathrm{~kg} \mathrm{~K} \mathrm{~K}_{2} \mathrm{O}$ /fed significantly increased vegetative growth characters of wheat plants in both growing seasons as showed in Table 2 . The highest averages of these characters were recorded with the high rate of potassium fertilizer $(56 \mathrm{~kg} \mathrm{~K} 2 \mathrm{O} / \mathrm{fed})$ in both growing seasons. It is noticed that using the high rate of potassium fertilizer caused increased in total chlorophyll by (15.32\%), flag leaf area by $(13.35 \%)$ and plant height by $(11.97 \%)$ compared with control treatment (without potassium fertilizer) as average over both growing seasons. The desirable effect of potassium on vegetative growth characters might be attributed to potassium has a greater effect on plant physiology and even in the plant morphology, which helps in root development, translocation of photosynthates products and regulator of ionic balance (Reddya et al., 2004), osmoregulation, enzyme activity (Wang et al., 2013), beside it is effect on the essential major elements chiefly nitrogen and phosphorus, which then positively reflected on vegetative growth characters (total chlorophyll, leaf area and plant height) of wheat plants. The recorded findings are in partial congruence of the results reported by Khan and Jan (2014) and Dincsoy and Sonmez (2019).

Notably, the interaction among zinc foliar application and potassium fertilizer rates treatments had a significant effect on vegetative growth characters as showed in Table 2. As showed in Figs. 1, 2 and 3. The top treatment of interaction which resulted the highest averages of total chlorophyll (Fig. 1), flag leaf area (Fig. 2) and plant height (Fig. 3) was foliar application with $450 \mathrm{~g}$ of $\mathrm{ZnSO}_{4} .7 \mathrm{H}_{2} \mathrm{O}$ beside top dressing with $56 \mathrm{~kg} \mathrm{~K}_{2} \mathrm{O} / \mathrm{fed}$ in both growing seasons. The second interaction treatment was foliar application with $450 \mathrm{~g}$ of $\mathrm{ZnSO}_{4} .7 \mathrm{H}_{2} \mathrm{O}$ beside top dressing with $32 \mathrm{~kg} \mathrm{~K} 2 \mathrm{O} / \mathrm{fed}$ and without significant between them in both growing seasons. While the lowest averages of these characters were recorded from the control treatment. The obtained results are in confidence with those recorded by Arif et al. 2017 and Sharma et al. (2018). 
Table 2: Total chlorophyll content, flag leaf area, plant height, number of spikes $/ \mathrm{m}^{2}$ and spike length as influenced by zinc foliar spraying levels and potassium fertilizer rates and their interaction during 2017/2018 and 2018/2019 seasons.

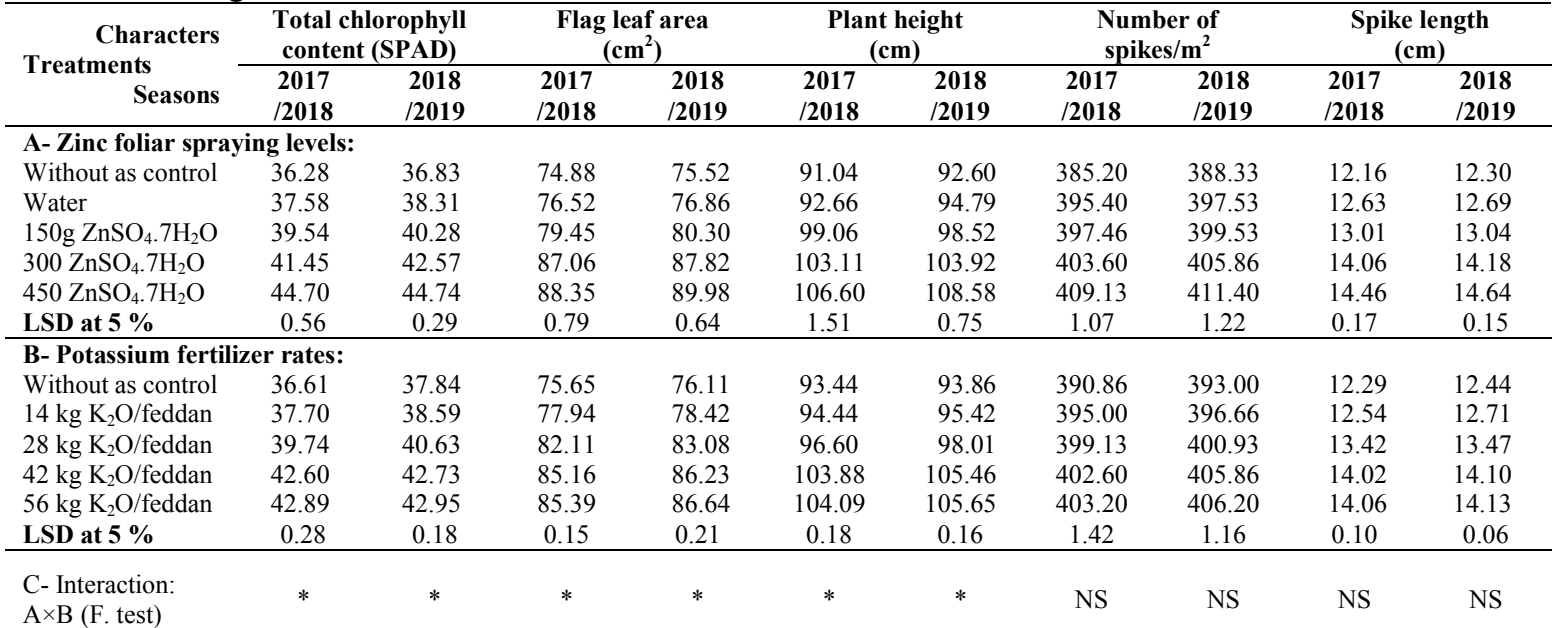

*; Significance at probability of 5\% level and NS; non-significant at probability of 5\% level.

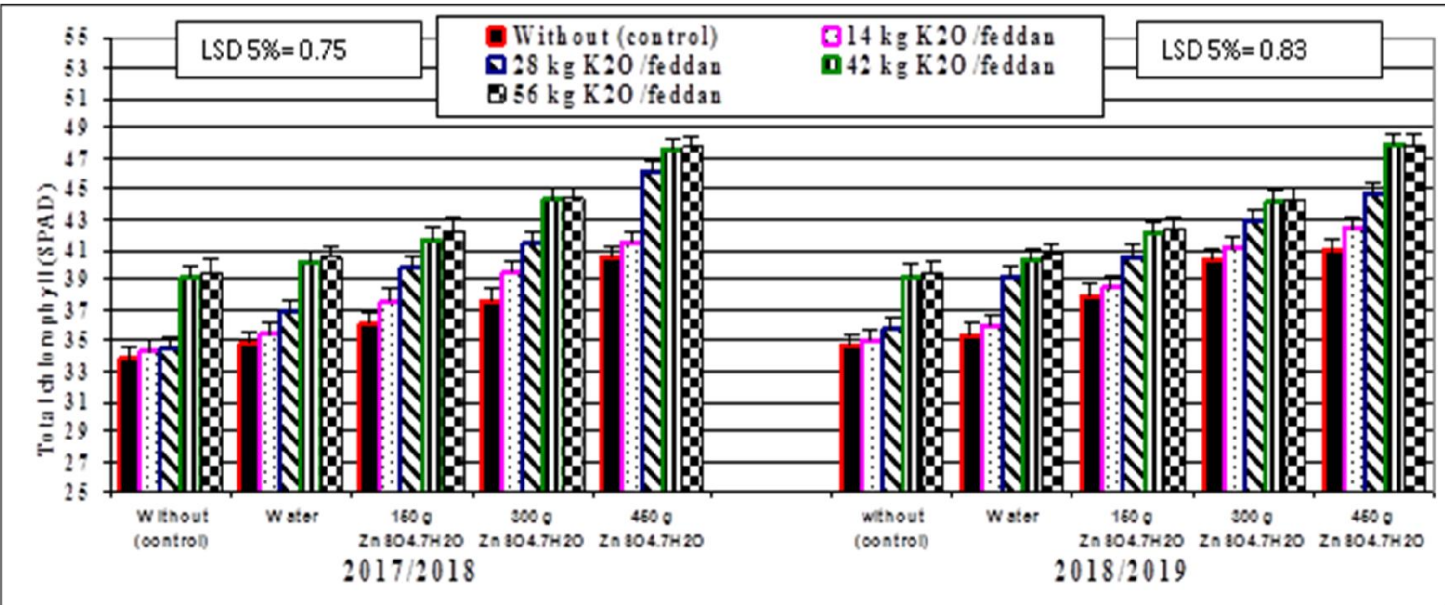

Fig. 1: Total chlorophyll (SPAD) as influenced by the interaction between zinc foliar spraying levels and potassium fertilizer rates during 2017/2018 and 2018/2019 seasons.

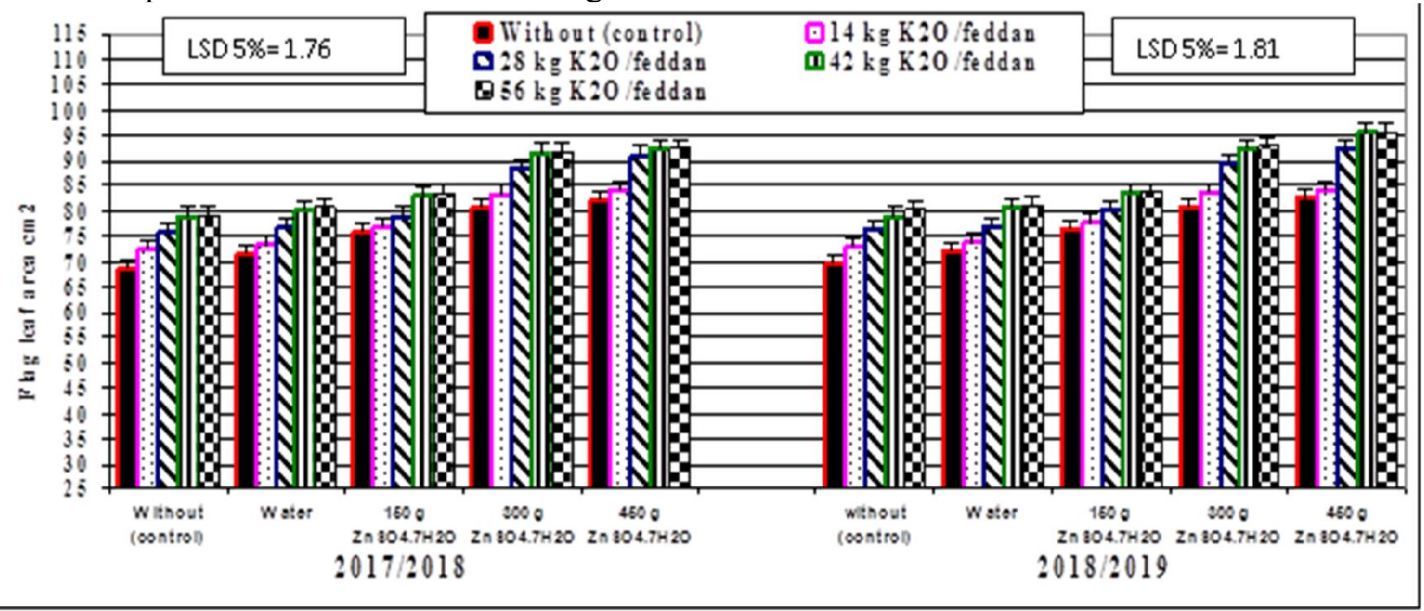

Fig. 2: Flag leaf area $\left(\mathrm{cm}^{2}\right)$ as influenced by the interaction between as affected by the interaction between zinc foliar spraying levels and potassium fertilizer rates during 2017/2018 and 2018/2019 seasons. 


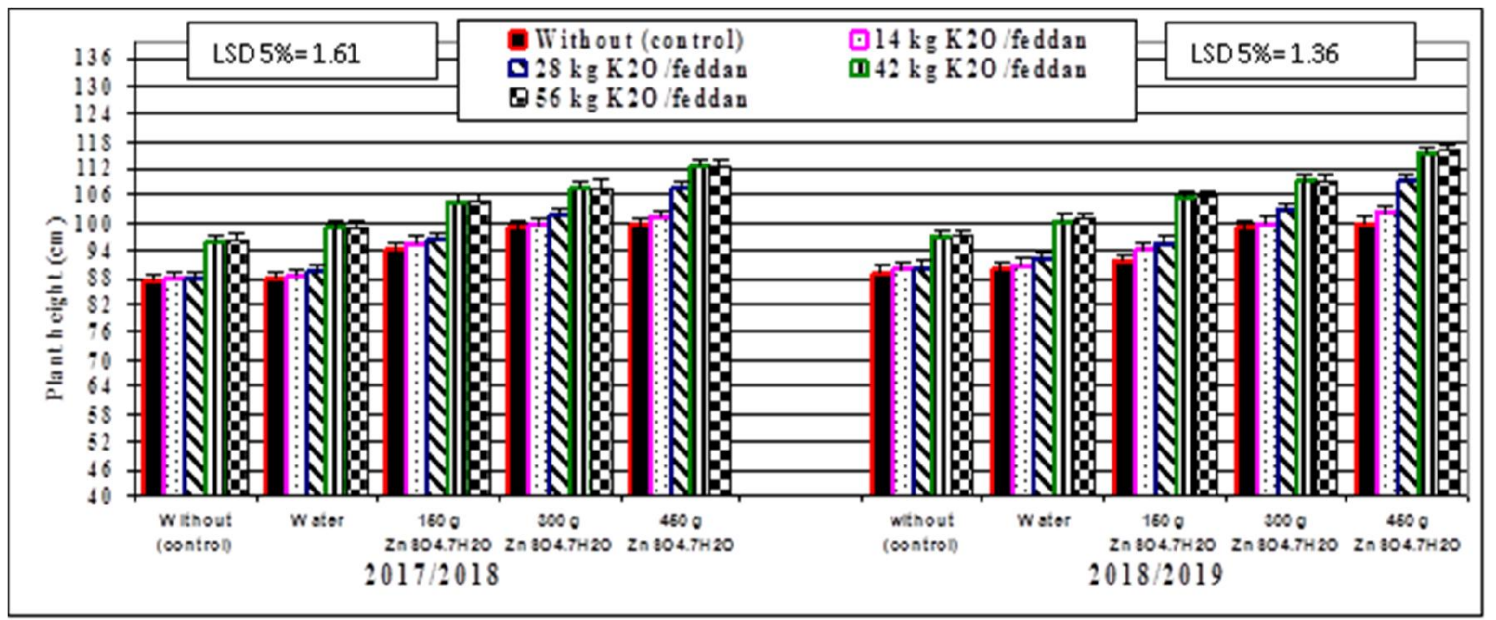

Fig. 3: Plant height $(\mathrm{cm})$ as influenced by the interaction between zinc foliar spraying levels and potassium fertilizer rates during 2017/2018 and 2018/2019 seasons.

\section{B-Yield and its attributes:}

Regarding the effect of zinc foliar application on yield and its attributes, data in Tables 2 and 3 clarify that foliar spraying with water and zinc levels significantly increased yield and its attributes in both seasons in comparison to control treatment. The maximum averages of yield and yield attributes were recorded with the foliar application with high level of zinc $\left(450 \mathrm{~g} \mathrm{ZnSO}_{4} .7 \mathrm{H}_{2} \mathrm{O}\right)$ as compared with other foliar treatments. In this regard, foliar application with $450 \mathrm{~g} \mathrm{ZnSO} 4.7 \mathrm{H}_{2} \mathrm{O}$ increased yield attributes i.e. number of spikes $/ \mathrm{m}^{2}$ by $(6.07 \%)$, spike length by $(18.96 \%)$, number of grains/spike by $(21.14 \%)$, grains weight/spike by $(28.64 \%)$ and 1000 -grain weight by $(20.04 \%)$ in comparison to control treatment (without foliar application) as average over both growing seasons. The obtained data also clearly presented that the high level of $\mathrm{Zn}$ foliar application $\left(450 \mathrm{~g} \mathrm{ZnSO} 4.7 \mathrm{H}_{2} \mathrm{O}\right)$ led to the maximum values of grains and straw yield/fed in both seasons. It could be noticed that, the increase in grains yield/fed reached about $(20.91,17.77,15.42$ and $7.81 \%)$ and straw yield reached about (15.09, $12.22,9.17$ and $4.51 \%$ ) due to foliar spraying with the high level of zinc in contrast to without foliar application, spraying with water, spraying with zinc at $150,300 \mathrm{~g} \mathrm{ZnSO} 4.7 \mathrm{H}_{2} \mathrm{O}$ as averages over both growing seasons respectively.

Table 3: Number of grains/spike, grains weight/spike, 1000-grain weight, grains and straw yields as influenced by zinc foliar spraying levels and potassium fertilizer rates and their interaction during 2017/2018 and 2018/2019 seasons.

\begin{tabular}{|c|c|c|c|c|c|c|c|c|c|c|}
\hline \multirow{2}{*}{$\begin{array}{l}\text { Characters } \\
\text { Treatments } \\
\text { Seasons }\end{array}$} & \multicolumn{2}{|c|}{$\begin{array}{c}\text { Number of } \\
\text { grains/spike }\end{array}$} & \multicolumn{2}{|c|}{$\begin{array}{c}\text { Grains weight/spike } \\
\text { (g) }\end{array}$} & \multicolumn{2}{|c|}{$\begin{array}{c}\text { 1000-grain weight } \\
\text { (g) }\end{array}$} & \multicolumn{2}{|c|}{$\begin{array}{l}\text { Grain yield } \\
\text { (ardab/fed) }\end{array}$} & \multicolumn{2}{|c|}{$\begin{array}{c}\text { Straw yield } \\
\text { (ton/fed) }\end{array}$} \\
\hline & $\begin{array}{l}2017 \\
/ 2018 \\
\end{array}$ & $\begin{array}{l}2018 \\
/ 2019 \\
\end{array}$ & $\begin{aligned} 2017 \\
/ 2018 \\
\end{aligned}$ & $\begin{array}{r}2018 \\
/ 2019 \\
\end{array}$ & $\begin{array}{r}2017 \\
/ 2018 \\
\end{array}$ & $\begin{array}{r}2018 \\
/ 2019 \\
\end{array}$ & $\begin{array}{c}2017 \\
/ 2018 \\
\end{array}$ & $\begin{aligned} 2018 \\
/ 2019 \\
\end{aligned}$ & $\begin{array}{c}2017 \\
/ 2018 \\
\end{array}$ & $\begin{array}{l}2018 \\
/ 2019 \\
\end{array}$ \\
\hline \multicolumn{11}{|c|}{ A- Zinc foliar spraying levels: } \\
\hline Without as control & 66.40 & 67.53 & 2.88 & 2.94 & 44.56 & 45.26 & 18.53 & 18.66 & 3.844 & 3.858 \\
\hline Water & 69.33 & 70.33 & 3.35 & 3.46 & 46.30 & 46.74 & 18.96 & 19.22 & 3.936 & 3.963 \\
\hline $150 \mathrm{~g} \mathrm{ZnSO}_{4} .7 \mathrm{H}_{2} \mathrm{O}$ & 73.00 & 75.33 & 3.46 & 3.56 & 48.62 & 49.19 & 19.31 & 19.65 & 3.978 & 4.143 \\
\hline $300 \mathrm{ZnSO}_{4} .7 \mathrm{H}_{2} \mathrm{O}$ & 75.20 & 76.93 & 3.57 & 3.71 & 49.82 & 50.95 & 20.73 & 20.98 & 4.152 & 4.331 \\
\hline $450 \mathrm{ZnSO}_{4} \cdot 7 \mathrm{H}_{2} \mathrm{O}$ & 79.93 & 82.33 & 3.58 & 3.91 & 53.37 & 54.46 & 22.17 & 22.80 & 4.370 & 4.495 \\
\hline LSD at $5 \%$ & 0.79 & 1.20 & 0.01 & 0.01 & 0.58 & 0.45 & 0.25 & 0.17 & 0.098 & 0.033 \\
\hline \multicolumn{11}{|c|}{ B- Potassium fertilizer rates: } \\
\hline Without as control & 69.00 & 70.53 & 3.07 & 3.14 & 45.60 & 46.36 & 18.33 & 18.63 & 3.974 & 4.063 \\
\hline $14 \mathrm{~kg} \mathrm{~K}_{2} \mathrm{O} /$ feddan & 71.06 & 72.26 & 3.28 & 3.32 & 46.90 & 47.73 & 19.20 & 19.46 & 4.021 & 4.110 \\
\hline $28 \mathrm{~kg} \mathrm{~K}_{2} \mathrm{O} /$ feddan & 73.13 & 75.53 & 3.40 & 3.58 & 48.96 & 49.74 & 19.70 & 20.20 & 4.074 & 4.166 \\
\hline $42 \mathrm{~kg} \mathrm{~K}_{2} \mathrm{O} /$ feddan & 75.20 & 76.80 & 3.52 & 3.74 & 50.48 & 51.34 & 21.14 & 21.38 & 4.135 & 4.211 \\
\hline $56 \mathrm{~kg} \mathrm{~K}_{2} \mathrm{O} /$ feddan & 75.46 & 77.33 & 3.58 & 3.79 & 50.72 & 51.43 & 21.32 & 21.64 & 4.076 & 4.229 \\
\hline LSD at $5 \%$ & 0.75 & 0.64 & 0.08 & 0.06 & 0.51 & 0.37 & 0.22 & 0.31 & 0.092 & 0.072 \\
\hline $\begin{array}{l}\text { C- Interaction: } \mathrm{A} \times \mathrm{B} \\
\text { (F. test) }\end{array}$ & $*$ & $*$ & * & $*$ & $*$ & $*$ & $*$ & * & $*$ & $*$ \\
\hline
\end{tabular}


The enhancement in grain and straw yields of wheat plant due to foliar application with zinc might be attributed to the fact that $\mathrm{Zn}$ plays vital role in maintaining balanced plant growth as previously mentioned and maximizing yield attributes, consequently enhancing grain and straw yields of wheat plants (Potarzycki and Grzebisz, 2009; Seadh et al., 2009; Galavi et al., 2011; Maleki et al., 2014 and Zhu et al., 2015). The recorded data are in coincidence with those recorded by El-Metwally et al. (2012); El-Habbasha et al. (2015); Ahmed Akram et al. (2017); El-Dahshouri (2018) and Hassanein et al. (2019). Moreover, similar results were recorded on rice and corn plants by Wasaya et al. (2017) and Muthukumararaja and Sriramachandrasekharan (2020).

The obtained results of the statistical analysis clearly showed that there were significant differences in yield and its attributes, where the addition rate of $56 \mathrm{~kg} \mathrm{~K}_{2} \mathrm{O} / \mathrm{fed}$ was significantly exceeded and recorded the highest averages of these characters than all other potassium fertilizer rates treatments. The corresponding data were $\left(403.20\right.$ and $\left.406.20 \mathrm{spike} / \mathrm{m}^{2}\right)$ for number of spikes $/ \mathrm{m}^{2},(14.06$ and $14.13 \mathrm{~cm}$ ) for spike length, (75.46 and 77.33 grains/spike) for number of grains/spike, (3.58 and $3.79 \mathrm{~g}$ ) for grains weight/spike, (50.72 and $51.43 \mathrm{~g}$ ) for 1000-grain weigh, (21.32 and $21.64 \mathrm{ardab} / \mathrm{fed})$ for grains yield/fed and (4.135 and 4.229 ton/fed) for straw yield/fed in both seasons respectively. On the other hand, there were no significant differences between the rate of 56 and $42 \mathrm{~kg} \mathrm{~K}_{2} \mathrm{O} / \mathrm{fed}$ in yield and its attributes. Generally, it could be noticed that the addition of high rate of potassium $56 \mathrm{~kg} \mathrm{~K}_{2} \mathrm{O} / \mathrm{fed}$ increased grains yield/fed by $(16.43,11.12,7.67$, and 1.03) and straw yield/fed by $(4.06,2.86,1.50$ and $0.93 \%)$ as compared with addition $\left(0,14,28\right.$ and $42 \mathrm{~kg} \mathrm{~K}_{2} \mathrm{O} /$ fed $)$ over both growing seasons, respectively. The increases in grains yield might be ascribed to the application of potassium fertilizer at the highest rate of $56 \mathrm{~kg} \mathrm{~K}_{2} \mathrm{O} / \mathrm{fed}$ might lead to improving growth characters and yield attributes through increasing (the productivity of the leaves during the process of photosynthesis, the efficiency of nitrogen, enzyme activity, diseases and cold resistance, the transfer of the carbohydrates from their formation in leaves to the grains (Reddya et al., 2004 and Wang et al., 2013). The obtained results are in agreement with those obtained by Tahir et al. (2008); Khan and Jan (2014); Brhane and Teka (2018) and Dincsoy and Sonmez (2019).

The interaction among foliar application and potassium fertilizer rates treatments had a significant effect only on number of grains/spike, grains weight/spike, 1000-grain weight, grains yield/fed and straw yield/fed as presented in Table 3. The recorded data clearly showed that foliar application with $450 \mathrm{~g}$ of $\mathrm{ZnSO}_{4} .7 \mathrm{H}_{2} \mathrm{O}$ besise the potassium rates of $56 \mathrm{~kg} \mathrm{~K} 2 \mathrm{O} /$ fed recorded the highest values of number of grains/spike (Fig. 4) grains weight/spike (Fig. 5), 1000-grain weight (Fig. 6), grains yield/fed (Fig. 7) and straw yield/fed (Fig.8) against the minimum values were obtained from the control treatment during both seasons. The increases in yield and yield attributes due to foliar application with $450 \mathrm{~g}$ of $\mathrm{ZnSO}_{4} .7 \mathrm{H}_{2} \mathrm{O}$ besise the potassium rates of $56 \mathrm{~kg} \mathrm{~K}_{2} \mathrm{O} / \mathrm{fed}$ might be ascribed to potassium has favorable effects on enhancing (growth characters, photosynthetic activity, cell division, elements uptake, the transfer of the carbohydrates and protein from their formation in leaves to the grains). Similarly, foliar application with $450 \mathrm{~g}$ of $\mathrm{ZnSO}_{4} .7 \mathrm{H}_{2} \mathrm{O}$ play a vital role in (chlorophyll biosynthesis, enzyme activation, pollen viability and pollen tube formation as well as increase seed set, starch utilization) consequently, increasing the amount of dry matter and grain as well as straw yields/fed of wheat plants. The finding results are in close compatible with those obtained by Jan et al. (2012); Arif et al. (2017) and Sharma et al. (2018). 


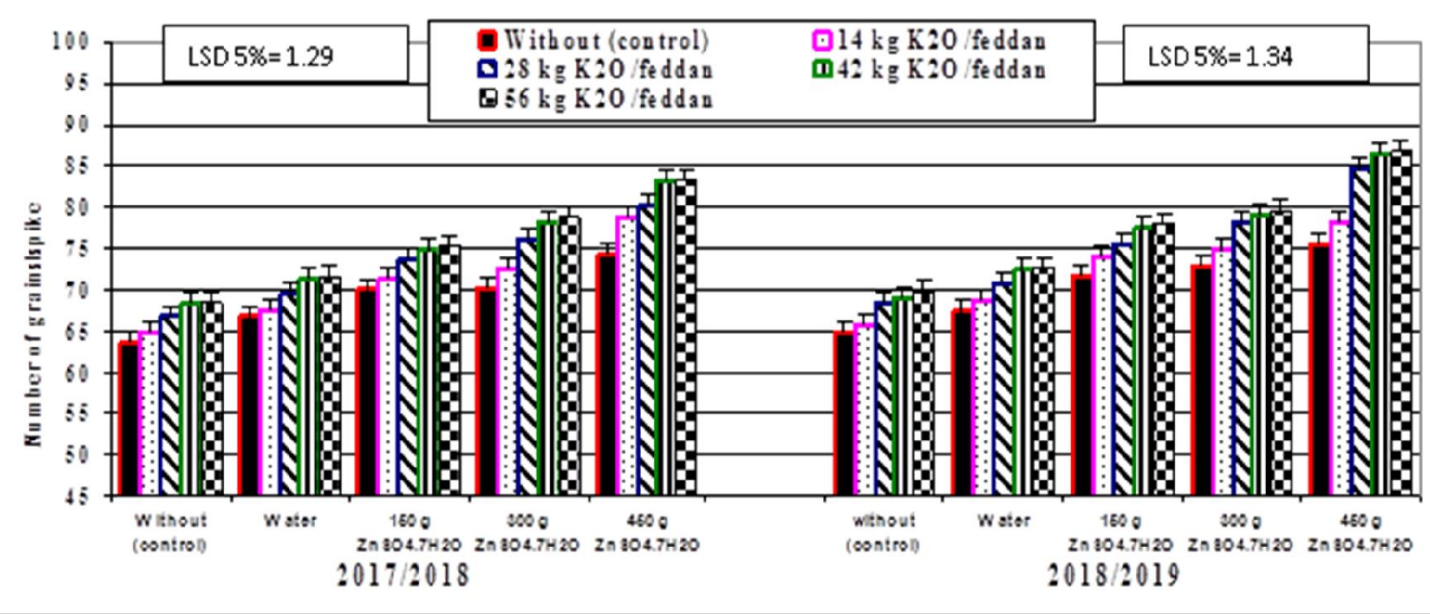

Fig. 4: Number of grains/spike as influenced by the interaction between zinc foliar spraying levels and potassium fertilizer rates during 2017/2018 and 2018/2019 seasons.

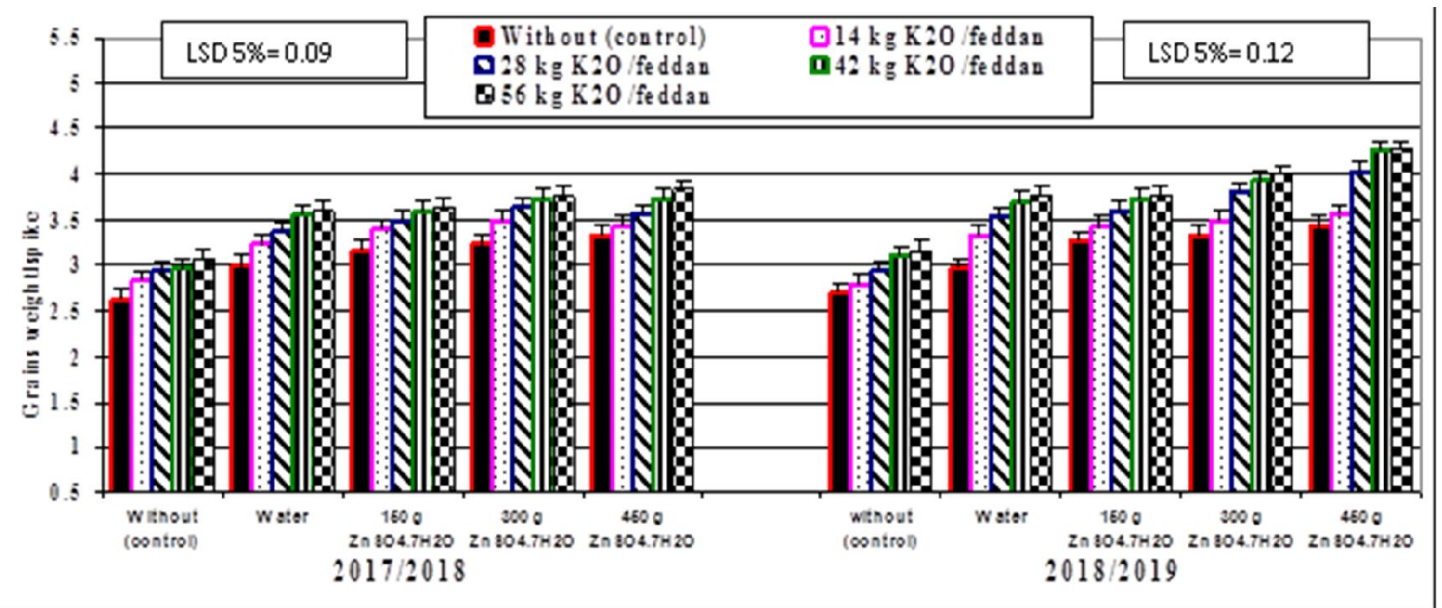

Fig. 5: Grains weight/spike as influenced by the interaction between zinc foliar spraying levels and potassium fertilizer rates during 2017/2018 and 2018/2019 seasons.

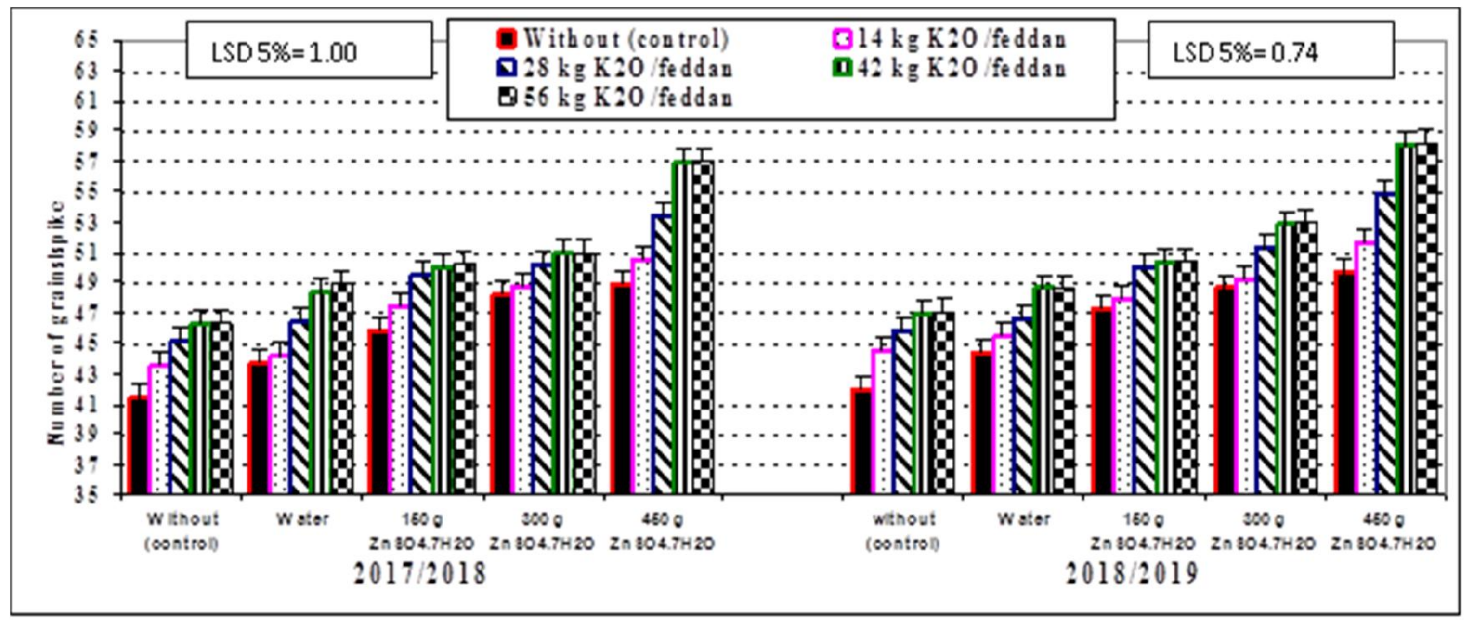

Fig. 6: 1000-grain weight ( $\mathrm{g}$ ) as influenced by the interaction between zinc foliar spraying levels and potassium fertilizer rates during 2017/2018 and 2018/2019 seasons. 


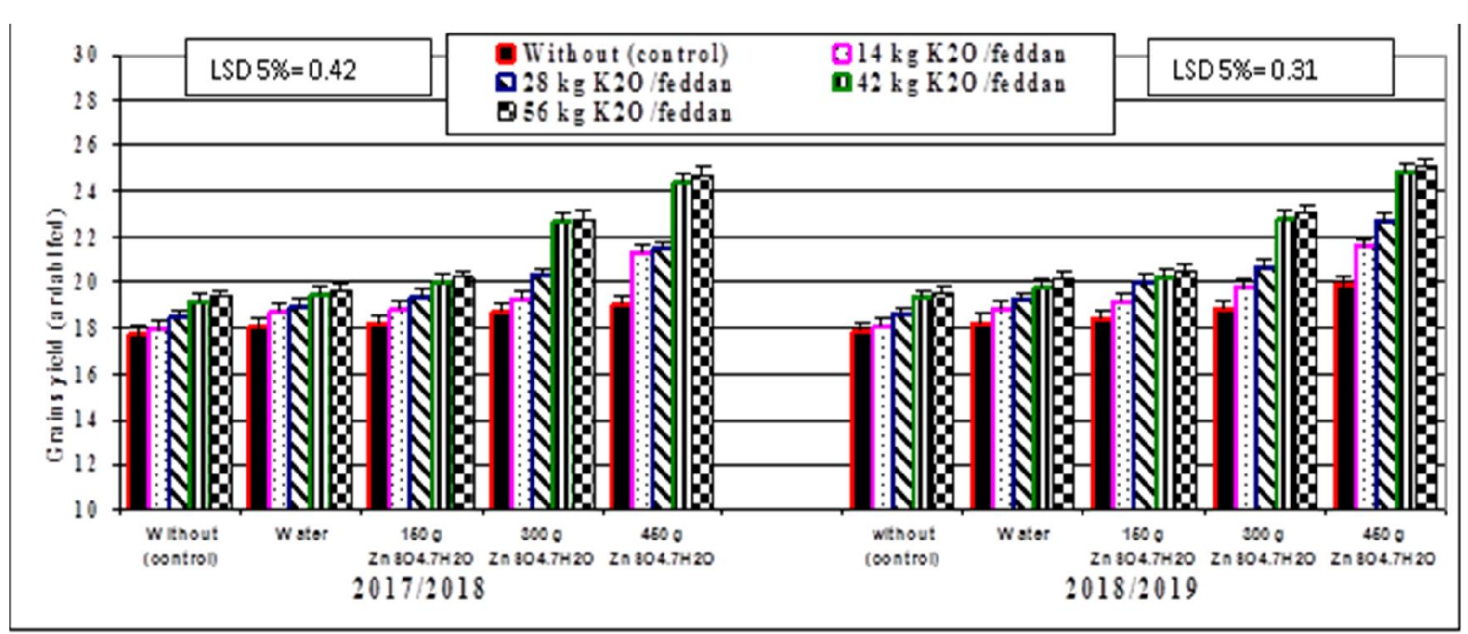

Fig. 7: Grains yield (ardab/fed) as influenced by the interaction between zinc foliar spraying levels and potassium fertilizer rates during 2017/2018 and 2018/2019 seasons.

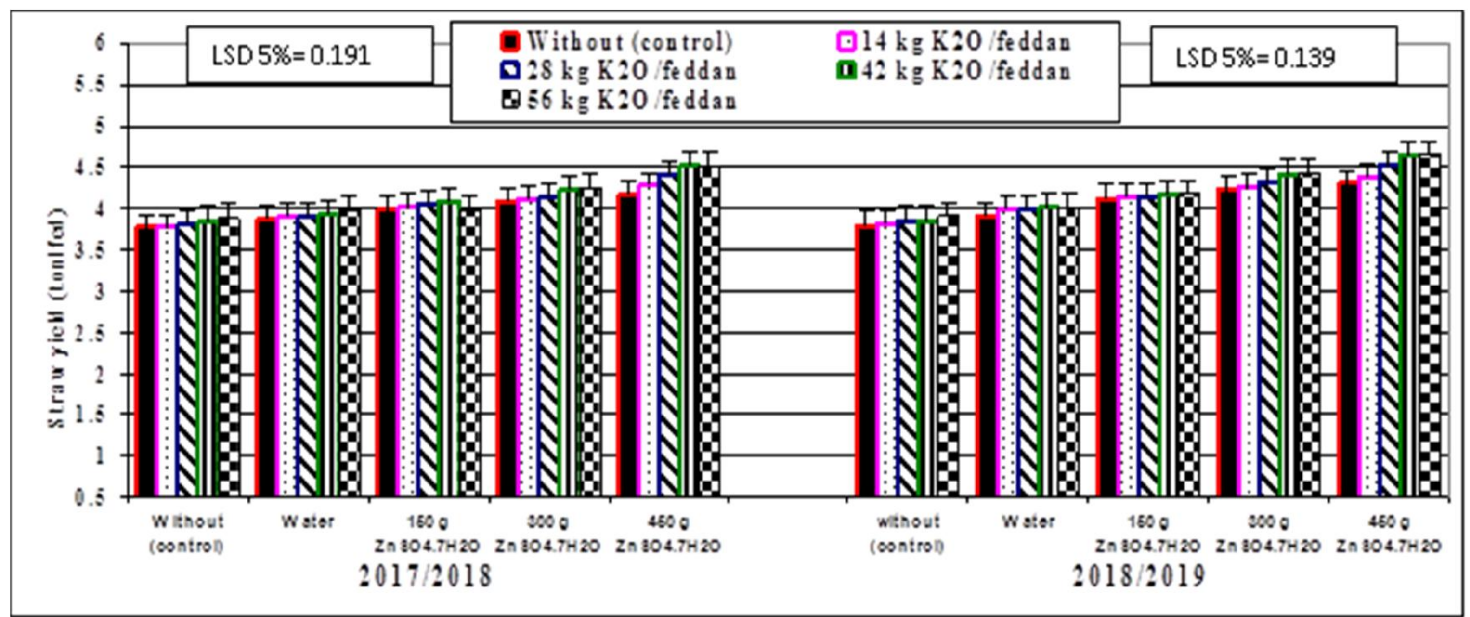

Fig. 8: Straw yield (ton/fed) as influenced by the interaction between zinc foliar spraying levels and potassium fertilizer rates during 2017/2018 and 2018/2019 seasons.

\section{C-Grains quality:}

Data presented in Table 4 clearly showed that foliar application treatments significantly increased grains quality of wheat grains compared to control treatment in both seasons. The highest values of carbohydrates (72.19 and $73.42 \%$ ), protein (13.50 and $13.78 \%$ ), phosphorous $(0.313$ and $0.280 \%)$, potassium (1.28 and 1.33\%) and zinc (50.69 and $52.14 \mathrm{ppm})$ were recorded when wheat plants spraying with $450 \mathrm{~g}$ of $\mathrm{ZnSO}_{4} .7 \mathrm{H}_{2} \mathrm{O}$ in the first and second seasons, respectively. However, the lowest averages of these characters were recorded with control treatment (without foliar application). This improvement in wheat grain quality due to foliar application with zinc improving growth characters, the uptake of most nutrients and accumulation of dry matter in grains, which reflected to increasing grain quality. These results are in close agreement with those indicated by Zeidan et al. (2010); El-Habbasha et al. (2015); Hassanein et al. (2019) and El-Dahshouri (2018).

The data presented in Table 4 showed that potassium fertilizer rates significantly effect on most grain quality, with exception phosphorous content during both seasons. The highest values of carbohydrates (69.46 and $71.58 \%$ ), protein (13.21 and $13.44 \%$ ), phosphorous $(0.293$ and $0.262 \%$ ), potassium (1.37 and $1.39 \%)$ and zinc (40.09 and $41.53 \mathrm{ppm})$ were resulted when wheat plants received $56 \mathrm{~kg} \mathrm{~K} 2 \mathrm{O} /$ fed in both seasons, respectively. In contrast, the minimum values of these characters were resulted from the plots not received potassium fertilizer. The increases in grains potassium content reached about $(20.61,15.00,12.21$ and $2.62 \%)$ and zinc content about $(10.04,7.66,3.88$ and $0.74 \%)$ as compared with $0,14,28$ and $42 \mathrm{~kg} \mathrm{~K}_{2} \mathrm{O} /$ fed over both growing seasons. The increases in grains quality 
due to the higher potassium fertilizer might be ascribed to the vital role of potassium in physiological, metabolic and biochemical of plants, which helps in translocation of photosynthates products to grains, protein synthesis. These results are similar with those obtained by Khan and Jan (2014) and Dincsoy and Sonmez (2019).

The interaction between zinc foliar application and potassium fertilizer rates significantly effect on potassium and zinc content as presented in Table 4. As illustrated in Figs. 9 and 10 the highest values of all grains quality were resulted from pots received $450 \mathrm{~g}$ of $\mathrm{ZnSO}_{4} .7 \mathrm{H}_{2} \mathrm{O}$ besise adding potassium fertilizer at the rate of $56 \mathrm{~kg} \mathrm{~K} 2 \mathrm{O} / \mathrm{fed}$ in comparison with control treatment in both seasons.

Table 4: Carbohydrates, protein, phosphorous, potassium and zinc contents in grains as influenced by zinc foliar spraying levels and potassium fertilizer rates and their interaction during 2017/2018 and 2018/2019 seasons.

\begin{tabular}{|c|c|c|c|c|c|c|c|c|c|c|}
\hline \multirow{2}{*}{$\begin{array}{c}\text { Characters } \\
\text { Treatments } \\
\text { Seasons }\end{array}$} & \multicolumn{2}{|c|}{ Carbohydrates (\%) } & \multicolumn{2}{|c|}{$\begin{array}{c}\text { Protein } \\
(\%)\end{array}$} & \multicolumn{2}{|c|}{$\begin{array}{c}\text { Phosphorous } \\
(\%)\end{array}$} & \multicolumn{2}{|c|}{$\begin{array}{c}\text { Potassium } \\
(\%)\end{array}$} & \multicolumn{2}{|c|}{$\begin{array}{c}\text { Zinc } \\
(\mathrm{ppm})\end{array}$} \\
\hline & $\begin{array}{l}2017 \\
/ 2018 \\
\end{array}$ & $\begin{array}{c}2018 \\
/ 2019 \\
\end{array}$ & $\begin{array}{l}2017 \\
/ 2018 \\
\end{array}$ & $\begin{array}{l}2018 \\
/ 2019 \\
\end{array}$ & $\begin{array}{l}2017 \\
/ 2018 \\
\end{array}$ & $\begin{array}{r}2018 \\
/ 2019 \\
\end{array}$ & $\begin{array}{c}2017 \\
/ 2018 \\
\end{array}$ & $\begin{array}{r}2018 \\
/ 2019 \\
\end{array}$ & $\begin{array}{c}2017 \\
/ 2018 \\
\end{array}$ & $\begin{array}{c}2018 \\
/ 2019 \\
\end{array}$ \\
\hline \multicolumn{11}{|c|}{ A- Zinc foliar spraying levels: } \\
\hline Without as control & 65.00 & 66.18 & 11.59 & 11.86 & 0.223 & 0.227 & 1.16 & 1.18 & 29.94 & 32.16 \\
\hline Water & 66.03 & 68.06 & 12.46 & 12.54 & 0.231 & 0.244 & 1.23 & 1.27 & 32.88 & 33.82 \\
\hline $150 \mathrm{~g} \mathrm{ZnSO}_{4} \cdot 7 \mathrm{H}_{2} \mathrm{O}$ & 68.87 & 72.01 & 12.95 & 13.10 & 0.244 & 0.250 & 1.26 & 1.30 & 37.20 & 38.96 \\
\hline $300 \mathrm{ZnSO}_{4} \cdot 7 \mathrm{H}_{2} \mathrm{O}$ & 70.66 & 73.10 & 13.35 & 13.56 & 0.251 & 0.260 & 1.27 & 1.32 & 41.19 & 42.21 \\
\hline $450 \mathrm{ZnSO}_{4} .7 \mathrm{H}_{2} \mathrm{O}$ & 72.19 & 73.42 & 13.50 & 13.78 & 0.313 & 0.280 & 1.28 & 1.33 & 50.69 & 52.14 \\
\hline LSD at $5 \%$ & 0.40 & 0.20 & 0.13 & 0.10 & 0.069 & 0.040 & 0.01 & 0.01 & 0.76 & 0.33 \\
\hline \multicolumn{11}{|c|}{ B- Potassium fertilizer rates: } \\
\hline Without as control & 67.23 & 68.71 & 12.15 & 12.34 & 0.233 & 0.240 & 1.11 & 1.18 & 36.36 & 37.81 \\
\hline $14 \mathrm{~kg} \mathrm{~K}_{2} \mathrm{O} /$ feddan & 67.98 & 70.11 & 12.48 & 12.68 & 0.240 & 0.247 & 1.19 & 1.21 & 37.06 & 38.76 \\
\hline $28 \mathrm{~kg} \mathrm{~K}_{2} \mathrm{O} /$ feddan & 68.78 & 70.96 & 12.90 & 13.10 & 0.246 & 0.253 & 1.21 & 1.25 & 38.62 & 39.95 \\
\hline $42 \mathrm{~kg} \mathrm{~K}_{2} \mathrm{O} /$ feddan & 69.28 & 71.43 & 13.11 & 13.28 & 0.250 & 0.259 & 1.32 & 1.37 & 39.78 & 41.24 \\
\hline $56 \mathrm{~kg} \mathrm{~K}_{2} \mathrm{O} /$ feddan & 69.46 & 71.58 & 13.21 & 13.44 & 0.293 & 0.262 & 1.37 & 1.39 & 40.09 & 41.53 \\
\hline LSD at $5 \%$ & 0.18 & 0.29 & 0.08 & 0.06 & NS & NS & 0.01 & 0.01 & 0.28 & 0.18 \\
\hline $\begin{array}{l}\text { C- Interaction: } \\
\mathbf{A} \times \mathbf{B} \text { (F. test) } \\
\end{array}$ & NS & NS & NS & NS & NS & NS & $*$ & $*$ & $*$ & $*$ \\
\hline
\end{tabular}

*; Significance at probability of 5\% level and NS; non-significant at probability of 5\% level.

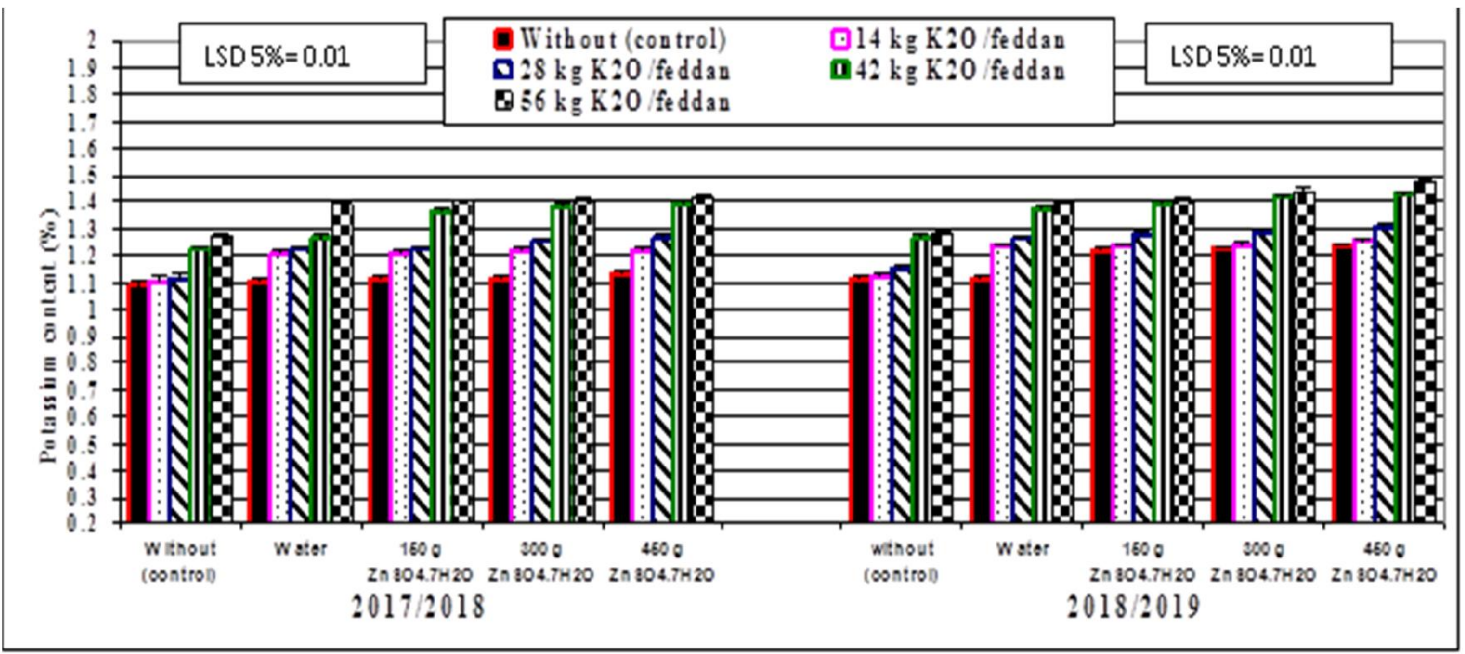

Fig. 9: Potassium content (\%) as influenced by the interaction between zinc foliar spraying levels and potassium fertilizer rates during 2017/2018 and 2018/2019 seasons. 


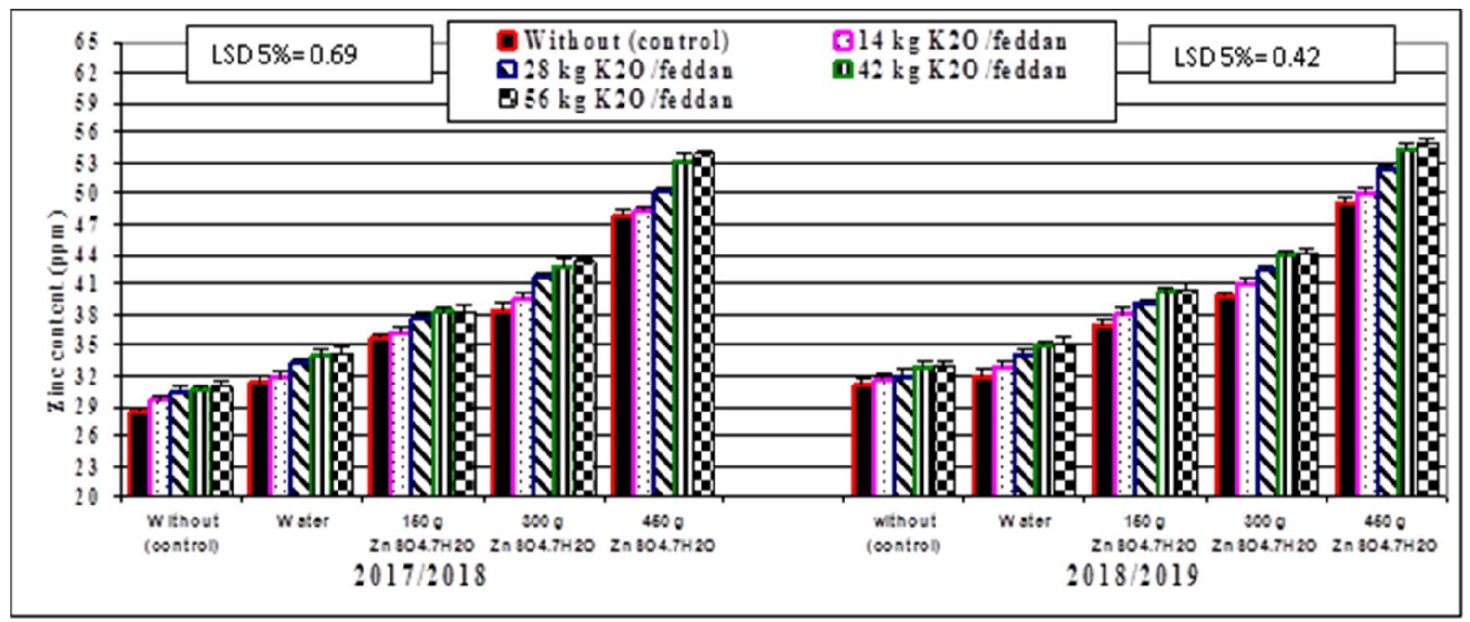

Fig. 10: Zinc content (ppm) as influenced by the interaction between zinc foliar spraying levels and potassium fertilizer rates during 2017/2018 and 2018/2019 seasons.

\section{Conclusion}

Findings of this study noticed that foliar application of zinc and potassium fertilizer levels significantly improved growth characters, yield and its attributes as well as grains quality of wheat plants. The highest values of the previous studied characteristics were resulted from foliar application with $450 \mathrm{~g} \mathrm{ZnSO}{ }_{4} .7 \mathrm{H}_{2} \mathrm{O}$ besides adding potassium as top dressing using $56 \mathrm{~kg} \mathrm{~K} 2 \mathrm{O} /$ fed and without significant differences when using the higher levels of zinc besides $42 \mathrm{~kg} \mathrm{~K}_{2} \mathrm{O} / \mathrm{fed}$ under the same ecological conditions of experiment site.

\section{References}

Ahmed, A., M., N. Depar, and M.Y. Memon, 2017. Synergistic use of nitrogen and zinc to bio-fortify zinc in wheat grains. Eurasian Journal of Soil Science, 6 (4): 319 - 326

AOAC. 2016. Official methods of analysis. $20^{\text {th }}$ Ed., Association of Official Analytical Chemists, Washington DC, USA.

Arif, M., M. Tasneem, F. Bashir, G. Yaseen, and A. Anwar, 2017. Evaluation of different levels of potassium and zinc fertilizer on the growth and yield of wheat. International Journal of Biosensors and Bioelectronics, 3(2): 1-5.

Brhane, H. and K. Teka, 2018. Optimum k fertilizer level for growth and yield of wheat (Triticum aestivum) in Cambisols of Northern Ethiopia. Asian Research Journal of Agriculture, 8(2): 18.

Cakmak, I. 2008. Enrichment of cereal grains with zinc: Agronomic or genetic biofortification? Plant Soil, 302: 1-17.

Dhillon, J.S., E.M. Eickhoff, R.W. Mullen, and W.R. Raun, 2019. World potassium use efficiency in cereal crops. Agronomy Journal, 111: 889-896.

Dincsoy, M. and F. Sonmez, 2019. The effect of potassium and humic acid applications on yield and nutrient contents of wheat (Triticum aestivum L. var. Delfii) with same soil properties. Journal of Plant Nutrition, 42(20): 2757-2772.

El-Dahshouri, M.F., 2018. Effect of zinc foliar application at different physiological growth stages on yield and quality of wheat under sandy soil conditions. Agricultural Engineering International: CIGR Journal, 19(5): 193-200.

El-Habbasha, E.S., E.A. Badr, and E.A. Latef, 2015. Effect of zinc foliar application on growth characteristics and Grain Yield of some wheat varieties under $\mathrm{Zn}$ deficient sandy soil condition. International Journal Chemtech Research, 8(6): 452-458.

El-Metwally, A., N.A. Khalil, M.M. El-Fouly, and M.F. El-Dahshouri, 2012. Growth, nutrients uptake and grain yield of some wheat cultivars as affected by zinc application under sandy soil conditions. Journal Plant Production, 3(5):773-783. 
Esfandiari, E., M. Abdoli, S.B. Mousavi, and B. Sadeghzadeh, 2016. Impact of foliar zinc application on agronomic traits and grain quality parameters of wheat grown in zinc deficient soil. Indian Journal of Plant Physiology, 21(3):263-270.

FAO 2020. Food and Agriculture Organization of the United Nations, FAOSTAT, FAO Statistics Division 2020, February 2020.

Fischer, R.A., 2008. The importance of grain or kernel number in wheat: A reply to Sinclair and Jamieson. Field Crops Research, 105(1-2): 15-21.

Galavi, M., K. Yosefi, M. Ramrodi, and S.R. Mousavi, 2011. Effect of bio-phosphate and chemical phosphorus fertilizer accompanied with foliar application of micronutrients on yield, quality and phosphorus and zinc concentration of maize. Journal of Agricultural Science, 3(4): 22-29.

Gomez, K.N. and A.A. Gomez, 1984. Statistical procedures for agricultural research. John Wiley and Sons, New York, $2^{\text {nd }}$ Ed., 68 P.

Hassanein M.S., N.M. Zaki, and A.G. Ahmed, 2019. Effect of Zn foliar application on growth and yield characteristics of two wheat cultivars. Current Science International, 8(3): 491-498.

Hotz, C. and K.H. Braun, 2004. Assessment of the risk of zinc deficiency in populations and options for its control. Food and Nutrition Bulletin, 2: 194-204.

Jackson, M.L., 1967. Soil chemical analysis. Prentica Hall Inc, Engleweed Cliffs, N.J.

Jan, M.T., M.J. Khan, F. Ullah, M. Arif, and M.Z. Afridi, 2012. Integrated management of crop residue and $\mathrm{N}$ fertilizer for wheat production. Pakistan Journal of Botany, 44(6): 2015-2019.

Jiang, L., D. Zhang, F. Song, X. Zhang, Y. Shao, and C. Li, 2013. Effects of zinc on growth and physiological characters of flag leaf and grains of winter wheat after anthesis. Advance Journal of Food Science and Technology, 5(5): 571-577.

Khan, A.A.I. and M.T. Jan, 2014. Impact of various nitrogen and potassium levels and application methods on grain yield and yield attributes of wheat. Sarhad Journal of Agricultural, 30(1):3546.

Maleki, A., S. Fazel, R. Naseri, K. Rezaei, and M. Heydari, 2014. The effect of potassium and zinc sulfate application on grain yield of maize under drought stress conditions. Advances in Environmental Biology, 8(4):890-894.

Mosali, J., K. Desta, and R.K. Teal, 2006. Effect of foliar application of phosphorus on winter wheat grain yield, phosphorus uptake, and use efficiency. Journal of Plant Nutrition, 29(12): $2147-$ 2163.

Muthukumararaja, T. and M.V. Sriramachandrasekharan, 2020. Influence of zinc and organics on rice yield and zinc Use efficiency in zinc stress soil. Plant Archives, 20, Supplement 1: 1477-1480.

Pandey, N., G.C. Pathak, and C.P. Sharma, 2006. Zinc is critically required for pollen function and fertilization in lentil. Journal of Trace Elements in Medicine and Biology, 20: 89-96.

Potarzycki, J., and W. Grzebisz, 2008. Effect of zinc foliar application on grain yield of maize and its yielding components. Plant, Soil and Environment, 55(12): 519-527.

Reddya, A.R., K.V. Chaitanya, and M. Vivekanandanb, 2004. Drought-induced responses of photosynthesis and antioxidant metabolism in higher plants. Journal of Plant Physiology, 161: 1189-1202.

Russell, D.F., 1986. MSTAT-C computer based data analysis software, Crop and Soil Science Department, Michigan State University USA.

Sadasivam, S. and A. Manickam, 1996. Biochemical Methods, $2^{\text {nd }}$ Ed., New Age International. India.

Seadh, S.E., M.I. El-Abady, A.M. El-Ghamry, and S. Farouk, 2009. Influence of micronutrients foliar application and nitrogen fertilization on wheat yield and quality of grain and seed. Journal of Biological Sciences, 9 (8): 851-858.

Sharma, D.K., A. Kumar, R. Kumar, S.K. Patel, B. Kumar, A.P. Singh, and V.K. Goswami, 2018. Effect of different level of potassium and zinc on growth, yield attributes and yield of late sown wheat (Triticum aestivum L.) under irrigated system. International Journal of Chemical Studies, 6(3): 2075-2079.

Snedecor, G.W. and W.G. Cochran, 1980. Statistical Methods. $7^{\text {th }}$ Ed. Ames Iowa: The Iowa State University Press.

Tahir, M., A. Tanveer, A. Ali, M. Ashraf, and A. Wasaya, 2008. Growth and yield response of two wheat (Triticum aestivum L.) varieties to different potassium levels. Pakistan Journal of Life Society Science, 6(2): 92-95. 
Vora, V.D., K.K. Kanzaria, P.D. Vekaria, V.L.Modhvadiya, G.B. Vekariya, and D.S. Hirpara, 2019. Effect of zinc fertilization on wheat yield under sandy loam soil. Journal of Pharmacognosy and Phytochemistry, 8(3): 2086-2088.

Wang, M., Q. Zheng, Q. Shen, and S. Guo, 2013. The critical role of potassium in plant stress response. International Journal of Molecular Sciences, 14(4):7370-7390.

Wasaya, A., M. Shahzad Shabir, M. Hussain, M. Ansar, A. Aziz, W. Hassan, and I. Ahmad, 2017. Foliar application of zinc and boron improved the productivity and net returns of maize grown under rainfed conditions of Pothwar plateau. Journal of Soil Science and Plant Nutrition, 17(1): $33-45$.

WHO., 2002. World Health Organization Report: reducing risks, promoting healthy life. World Health Organization, Geneva, Switzerland.

Zeidan, M.S., M.F. Mohamed, and H.A. Hamouda, 2010. Effect of foliar fertilization of Fe, Mn and Zn on wheat yield and quality in low sandy soils fertility. World Journal of Agricultural Sciences, 6(6): 696-699.

Zhu, J., K.X. Zhang, W.S. Wang, W. Gong, W.C. Liu, H. G. Chen, and Y.T. Lu, 2015. Low temperature inhibits root growth by reducing auxin accumulation via ARR1/12. Plant and Cell Physiology, 56(4): 727-736. 